\title{
Recognitive Justice and Educational Inequalities: An Intersectional Approach Involving Secondary Grade School Students in Greece
}

\author{
Christos Govaris ${ }^{1, *}$, Wassilis Kassis $\left.{ }^{2} \mathbb{(}\right)$, Dimitris Sakatzis ${ }^{1}$, Jasmin-Olga Sarafidou ${ }^{1}$ and Raia Chouvati ${ }^{1}$ \\ 1 Department of Primary Education, University of Thessaly, 38221 Volos, Greece; sakatzhs@gmail.com (D.S.); \\ sarafidou@uth.gr (J.-O.S.); raiachouvati@uth.gr (R.C.) \\ 2 School of Education, University of Applied Sciences and Arts Northwestern Switzerland, \\ 5210 Windisch, Switzerland; wassilis.kassis@fhnw.ch \\ * Correspondence: govaris@uth.gr
}

check for updates

Citation: Govaris, C.; Kassis, W.; Sakatzis, D.; Sarafidou, J.-O.; Chouvati, R. Recognitive Justice and Educational Inequalities: An Intersectional Approach Involving Secondary Grade School Students in Greece. Educ. Sci. 2021, 11, 461. https://doi.org/10.3390/ educsci11090461

Academic Editor: Eleanor Dommett

Received: 12 June 2021

Accepted: 19 August 2021

Published: 25 August 2021

Publisher's Note: MDPI stays neutral with regard to jurisdictional claims in published maps and institutional affiliations.

Copyright: (c) 2021 by the authors. Licensee MDPI, Basel, Switzerland. This article is an open access article distributed under the terms and conditions of the Creative Commons Attribution (CC BY) license (https:/ / creativecommons.org/licenses/by/ $4.0 /)$.

\begin{abstract}
Adopting the theoretical approach of recognitive justice and the degree of students' recognitive experiences regarding empathy, respect, and social esteem, the present study focused on educational inequalities in the multicultural school and the factors that affect their appearance and reproduction. We examined the existence of social relations' differences in a sample of 1303 students from 69 secondary schools in Greece, using a questionnaire constructed to investigate students' recognitive experience of their relationships with teachers. By applying an intersectional approach, mainly through multiple regression analysis and multivariate interaction tests with MANOVA, we were able to identify that migrant students and students from families with a low educational level experienced a significantly lower degree of recognition, mainly with the forms of respect and social esteem, both in their relationships with teachers and with peers. Additionally, levels of recognition among teachers explained the large amount of variability in academic achievement and self-esteem, while higher levels of recognition among peers were a significant predictor of the respective students' higher self-esteem. These deficits in recognition concern pedagogical practices that deprive these groups of students of opportunities and possibilities for equal participation in teaching and school life.
\end{abstract}

Keywords: recognitive justice; inequality at school; intersectionality; recognition by teacher; recognition by peers; academic achievement; self-esteem

\section{Introduction}

Much research points out the fact that the quality of the relationships which are developed during educational processes between the members of a school community has a huge impact on the outcomes of school adaptation, learning, and achievement. More specifically, the quality of positive relationships between teachers and students [1-6], as well as between classmates [3,7-9] fosters school climate [10]. Positive relationships at school are strong predictors of students' emotional, cognitive, and social development, as well as their school performance [1,11-13].

The quality of social relationships at school do not affect all students to the same extent. Students with an immigrant background $[14,15]$ and/or from families with disadvantaged socio-economic status [16,17] are more affected by the quality of social relationships at school than their classmates from privileged social environments. It has been found that teachers maintain stereotypes towards the different levels of socio-economic background of students as well as their learning abilities [18-20]. Additionally, the stereotypical treatment of students with an immigrant background or from a disadvantaged socio-economic environment is significantly associated with low school performance [21] and the students in these groups are benefiting to a greater extent than their classmates by high quality relationships at school. 
Despite the fact that the systemic exploration of school inequalities are not the main goals of aforementioned research, they provide us with valuable information about the role that pedagogical relationships may play in the emergence and reproduction of these inequalities.

The investigation of factors which provoke school inequalities also demands a relational approach which explicitly interprets the presumptions of achievement of social or educational equality. In other words, the request is to identify and apply empirically an approach, which could inform us about the criteria that social or pedagogical relationships should fulfil to prevent the emergence of social or school inequalities. We believe that the theory of recognition, which was formulated by Honneth [22-24] and in particular its specialization as the theory of recognitive justice in the field of education by Stojanov [25-27], is more helpful in investigating and understanding the role that social relations play in schools regarding the production of educational inequalities. The recognition theory, as a theory of educational justice, defines clearly, as we will see below, specific qualitative criteria that must be met by schools to ensure that all students-without exception-are supported in the acquisition of experiences of recognition in the context of daily school life. These experiences of recognition are defined theoretically as the fundamental requirements for moral, cognitive, and social development of all students. Therefore, they are also basic conditions for school adaptation and school success.

\subsection{Recognition: A Fundamental Condition of Justice}

The theory of recognition is a theory of social justice. Honneth $[21,24]$ supports the claim that individual self-realization and autonomy constitute the main goals of the equal treatment of all individuals in society. A society is just and fair when it ensures the quality of intersubjective recognitive relations, which is a necessary condition for the formation of an intact personal identity. The core of social justice comprises the following three and equal forms of recognition: love, respect, and social esteem. The attainment of personal self-realization and autonomy presuppose the social experience of these three forms. Stojanov $[25,26,28]$ took into account Honneth's theory of recognitive justice and formulated a special approach to educational justice that differed significantly from other relevant approaches, (e.g., distributive justice). According to Stojanov, the concept of subjective development comprises two dimensions [25,26]: (a) the development of relationships with oneself (self-confidence, self-respect, and self-esteem); and (b) the development of relations with the world (e.g., deals, propositions, and subjective theories). Honneth does not refer to the second dimension, though, according to Stojanov, it is at the core of education. He also acknowledges that the forms of recognition Honneth proposes (i.e., empathy, respect, and social esteem) are key components in the quality of pedagogical relationships in school. From a philosophico-pedagogical point of view, he negotiates and expands the contents of these three forms of recognition to include the second dimension of individual development, that of the development of individual relations with the world (which means the broadening of the student's horizons). Honneth points out that a pedagogical theory of educational justice refers to school-age individuals who are not yet able, on account of their limited development of a range of skills, to make decisions and behave as mature and autonomous subjects.

\subsection{Empathy, Respect and Social Esteem According to Stojanov's Approach of Recognitive Justice}

Empathy is not defined simply as a fundamental condition for the developing person to experience their needs and desires as basic features of their personality per Honneth; it is a fundamental condition for experiencing their ideals and their life plans as important elements of their relations with the world [25]. Helsper and Lingkost [29] point out that empathy is an important factor in generating feelings and relationships of trust on the part of students. If experiences of this form of recognition are incomplete, feelings of fear, insecurity, neglect, and devaluation can result. These feelings can interfere with the students' identification with their school environment and lead them gradually to 
emotional isolation from other school community members and to failure at school. With this in mind, the insufficient experiences of empathy are evidence of unequal treatment in the school environment.

Honneth refers to respect as a form of recognition [22,24], namely, the recognition of the individual as a subject with a capacity for moral judgment (i.e., as a subject capable of recognizing the effects of their actions and taking responsibility for them). According to Stojanov [26], this form of recognition presupposes a subject who is cognitively fully mature and morally responsible, which does not apply in the case of those who are in the process of acquiring these exact abilities through education (i.e., students). For this reason, it is necessary to redefine the content and respect for the case of pedagogical relationships at school and take into account Peters' [30] definition of respect as a person's ability to form and hold their own perspective, have intentions, choose values, formulate assumptions, and make decisions. Because these abilities are expressions of the subjectivity of the individual they must be recognized, even if one disagrees with them or characterizes them as "immature" or "irrational" [26]. Based on this definition, pedagogical relationships function and are experienced as relationships of respect, wherein teachers encourage students to participate in lessons by allowing them to present their own interpretive standards and express their particular perspectives. When the school is interested in and takes care to ensure the active participation of all students, then it meets the norm of respect because it accepts them (without exception) as subjects who are able to discuss the lessons and issues of school life, describe their experiences, and offer their judgments [31]. On the other hand, insufficient experiences of respect on behalf of students refer to a school reality which does not provide opportunities for equal participation of all students in teaching and school life.

Stojanov emphasizes the importance of respecting the individuality of students not only in its abstract-formal but also in its specific personal dimension and expression. According to Honneth, social esteem (the third form of recognition) refers to the particular traits that characterize individual difference. It correlates the recognition of these traits with their capacity to contribute to the achievement of more general social goals, values, and objectives that accord with the cultural self-perception of a society [22]. Stojanov [26,27], on the other hand, argues that social esteem should be related not only or even primarily to job benefits but also to the individual's ability to display personal skills (as they relate to their autobiography/life experience). Experiences of social esteem constitute for the individual an important condition for the realization of potential, through which they will be able to contribute to society and thus become a full member of it [26]. Students can only develop their abilities and build positive self-esteem when their potential is recognized [26,31]. According to Helsper and Lingkost [29], experiences of social esteem constitute the condition of one student being recognized as separate from all others. In other words, the insufficient experiences of social esteem refer to the lack of pedagogical perceptions and respective practices of recognizing the diversity that characterizes the student population in the contemporary school environment.

The distinction between the three forms of recognition is drawn mainly for analytical purposes because at the level of everyday school life, all three are closely related to each other. For example, a lack of experience of respect and social esteem can result in the student losing — at an emotional level—their trust in the teacher [32].

\subsection{What Do the Insufficient Experiences of Recognition Cause at School? Some Empirical Data}

To date, little research has been conducted on the role and importance of recognition experiences in the school environment for the procedure of students' school adaptation. This research is based on Honneth's theory of recognition, using qualitative research methods and focusing on the study of students' school failure from the point of view of their own needs. From the findings, it is evident that students who experience a lack of emotional support from teachers are prevented from developing trusting relationships with them, and as a result, they cannot identify with them [33]. This leads to the creation 
of learning barriers; students are then unable to relate the complex cognitive content of teaching to their personal experience, so it has no personal meaning. This means, as Wiezorek underlines [34] that students who do not have emotional support feel that their own worldview and their learning interests are devalued. The important role of empathy experiences in creating strong bonds between students and school, motivating them to actively participate in teaching, have been underlined by the meta-analyzes of CorneliusWhite [35] and Roorda et al. [4]. Furthermore, teachers' empathy creates positive conditions for inclusive teaching and communication in the classroom, as well as contributing to the weakening of prejudices against students from minority groups. This is particularly important for the recognition of cultural differences in school [36].

A lack of emotional support and respect is associated with learning disabilities as well as low learning outcomes. Vieluf and Sauerwein [37] show that students with an immigrant background experience less respect than their native classmates due to low learning expectations from their teachers and reduced opportunities for participation in dialogue and cognitive processing of learning content. These lack of respect experiences are associated with low learning outcomes. Several other studies have revealed that immigrant students, as well as students from disadvantaged social backgrounds, are often faced with reduced teacher expectations regarding their learning abilities [38-41]. By contrast, a learning environment characterized by respectful relationships motivates students to participate in lessons, collaborate with their teachers and classmates, and become involved in society [42-45]. Therefore, students' incomplete respect experiences seem to be connected with the existence of unequal opportunities for participation in class and generally, in school life.

A lack of social esteem in students' relationships with their teachers has significant negative effects. Wiezorek [34] reports that students with a low school performance state that they regard poor social esteem as an underestimation of their personality. From the scope of recognition theory, special significance is given to the evaluation process of personal achievements, according to Prengel [46] because this theory produces and maintains stereotypes for "weak" students, and these are accompanied by discrimination and learning barriers, thus contributing to the consolidation of educational inequalities.

The students' recognition experiences with their teachers also affect their relationships with the other class members [46]. When the teacher places great emphasis on individual performance, for example, thus cultivating a climate of competition among students, they define as the basic criterion of recognition the norm of high individual performance. In conditions of fierce school competition, low-achieving students are systematically deprived of experiences of support and acceptance from their classmates, which leads to the creation of conditions for their marginalization [33].

To conclude, the evidence that derives from the limited research shows that the lack of recognition that is experienced by some students in their relationships with their teachers (educators) and their classmates, has a negative effect in the process of their school adaptation and performance. According to recognition theory the causes that result to experiences of lack of recognition are related to the institutional organization of the educational process both at a macro-level (such as students' evaluation regulations) and at a micro-level (such as the culture of an educational community).

\subsection{An intersectional View of Recognition Experiences}

Researchers studying the quality of pedagogical relationships in school and the groups of students who are most affected by them, either positively or negatively, usually consider the categories of ethnicity, the socio-economic or educational level of the students' families, and gender. In quantitative research, these categories are usually examined separately from each other $[47,48]$. This approach, however, presents significant limitations in understanding such a complex phenomenon as educational inequality. The groups of students are constructed and presented on the axis of each category as internally homogeneous, 
without considering cases of difference. This is a consequence of the complex relationships and interactions between the categories $[49,50]$.

The intersectional approach offers the possibility of overcoming the above-mentioned limitations, as it focuses on the study of the emergence of social and educational inequalities as phenomena related to the multiplicity of overlaps, intersections, and interdependencies between categories of ethnicity, socio-economic background, and gender. The concept of intersectionality originates from feminist, gender, and race studies [51] and is currently used in (mainly qualitative) educational research to understand the educational inequalities grid [52]. The central idea of this is that students from minority groups belong to more than one social group at the same time and experience interrelated discrimination both at an individual and institutional level [53]. Therefore, the intersectional approach offers opportunities to analyze qualitative differences and similarities within groups and multiple, cross-sectional inequalities between those groups [54]. The interdisciplinarity lens is particularly useful in the case of immigrant students because it prevents monothematic analysis based on ethnicity [55] and focuses on the dynamics developed by the interaction of students' different social situations, such as gender, socioeconomic status, ethnicity, and immigration background [48,50].

Empirically, we applied McCall's complex intersectionality theory [54], which combines the categories of migration, gender, and complex insights on how recognition experiences by teachers and classmates are distributed within the students' population. This approach will allow us to detect by our analytic strategy social intersections and address a more complex reality [56]. In doing so, we did not introduce intersectionality simply as an analytical toolkit for a more concise prediction of the respective models that are being estimated, but as a means of addressing power relations within those intersections [57]. Following this line of reasoning, through our analyses we are expecting to identify migrant adolescent students as not a homogenous group but rather one in which nuances of gender and socio-economic status pertain [58]. Combining migration, gender, and socio-economic status opens a more appropriate gateway to understanding students' development in school [59] when it comes to recognition experiences and their effects on academic achievement. Understanding the power relations created by the synthesis of the intersecting aspects of a student's identity in the context of their immigrant background facilitates their integration and development within the educational process [60]. Therefore, the main research issue that arises in relation to educational inequalities is the degree to which the students feel recognized by the school.

\section{Materials and Methods}

\subsection{Study and Sample}

The present study investigated recognition experiences of adolescent students in Greece. The study population consisted of students attending upper secondary school (Lykeio) in Greece. Students typically enter either a general (GEL) or a vocational (EPAL) Lykeio at 15 and graduate when they are 18. The sample included 1,303 students from 46 GELs (876 students) and 23 EPALs (427 students). The number of schools selected from each educational district was proportional to the population size of the district. Within each district, schools were selected by convenience sampling, keeping the same ratio of general to vocational students in the district. Participating schools were asked to engage students in one or two of their classes [20-30 students in total]. Students in the first grade comprised $37 \%$ of the sample, $39 \%$ in the second grade, and $22 \%$ in the third grade; 20 students were older than 18 . The proportion of females in the final sample was $53 \%$ (462 female and 414 male students) among participants attending GELs; it was $36 \%$ (156 female and 271 male students) among those attending EPALs. This reflected the different gender distribution among students within the corresponding type of school. Most of the participating students (67\%) were living in urban areas. 


\subsection{Analytic Strategy/Research Questions}

The following research questions were addressed by our analytic strategy:

- Do students differ in the degree they perceive themselves as being recognized by their teachers and their peers in different domains (moral respect, empathy, and social esteem)?

- Do students differ in the degree they perceive themselves as being recognized by their teachers and peers, according to their gender, ethnicity (i.e., Greek or non-Greek), and family education level?

- Does combining migration, gender, and socio-economic status open a more appropriate gateway in understanding the development of students?

- Is recognition by peers associated with recognition by teachers?

- Is recognition by teachers and peers associated with academic achievement and self-esteem?

- Which of the previously mentioned socio-demographic variables and recognition experiences are predictive of students' academic achievement and self-esteem?

\subsection{Measures}

Experiences of Recognition

Student experiences of recognition by their teachers and peers were measured using two scales, one on recognition by teachers and one on recognition by peers, with three subscales each, constructed by the authors for the present study. The items included in each scale were informed by theoretical considerations concerning the construct of "recognition" [61] and enhanced by items elicited from semi-structured interviews with 20 students attending GELs or EPALs in the Larissa prefecture. The items in each scale referred to three subscales concerning (a) moral respect; (b) empathy; and (c) social esteem.

Respect items referred to the freedom of students to express judgments that were respected and recognized by teachers and classmates; for instance, "Because I am not a hard-working student, teachers underestimate me" or "My classmates believe in me and my abilities." We applied eight teacher and nine peer respect items.

Empathy items, four items on empathy from teachers and three on empathy from peers, referred to the emotional support and encouragement that students received from teachers and classmates as well as the degree of trust they developed with them; for instance, "Teachers are not interested in my feelings" or "My classmates are interested in my emotional state".

Social esteem items, four items on empathy from teachers and six on empathy from peers, referred to the recognition of students' special abilities, characteristics, and achievements by their teachers and classmates that made them feel worthy of contributing to the goals and objectives of the school community; for instance, "My teachers' behavior shows they consider my presence important for the class" or "My classmates treat me as inferior".

Items in all six subscales were measured on a 6-point Likert-type scale $(1=$ not at all to $6=$ absolutely true). Scores for the total scales and subscales were calculated by averaging the relevant items, after reversing coding in case of negatively phrased statements. All scales and subscales showed high levels of reliability (Table 1).

Table 1. Reliability of the applied six recognition subscales.

\begin{tabular}{cccc}
\hline & Scales and Subscales & Cronbach's Alpha & Number of Items \\
\hline \multirow{2}{*}{ Recognition by } & Respect & 0.88 & 8 \\
Teachers & Empathy & 0.75 & 4 \\
& Social Esteem & 0.73 & 4 \\
& Total & 0.90 & 16 \\
\hline \multirow{4}{*}{ Recognition by Peers } & Respect & 0.87 & 9 \\
& Empathy & 0.78 & 3 \\
& Social Esteem & 0.79 & 6 \\
& Total & 0.89 & 18 \\
\hline
\end{tabular}


Self-esteem was measured by combining the 10 items of the Rosenberg scale (1965) and four items, concerning general self-esteem, from the 58 items of the Coopersmith scale (1981). This combined scale uses a variety of questions to assess emotions (positive and negative) and qualities of the individual, for instance, "I take a positive attitude towards myself" (Rosenberg) or "It is difficult to accept myself I am" (Coopersmith). Each item was answered on a 4 -point scale ( $1=$ strongly disagree to $4=$ strongly agree) and the total score for each student was calculated by averaging their answers after reversing the codes for negatively stated items. The reliability of the scale was high (Cronbach's alpha $=0.879$ ). Academic achievement was recorded based on the students' statements about their previous year's final grade [10].

A student was considered as having non-Greek ethnicity if they or at least one of their parents had been born in a country other than Greece. Family educational level was categorized as basic (up to 9 years of schooling), secondary (10-12 years), or higher (at least university level), with reference to the most educated parent.

\section{Results}

\subsection{Recognition by Teachers}

\subsubsection{Subscales of Recognition by Teachers}

The mean score of the total scale was 4.01 (SD = 0.96), reflecting "rather positive" experiences. The mean scores of all three teachers' recognition sub-scales were around the scale's midpoint, with moral respect being higher (Figure 1 and Table 2).

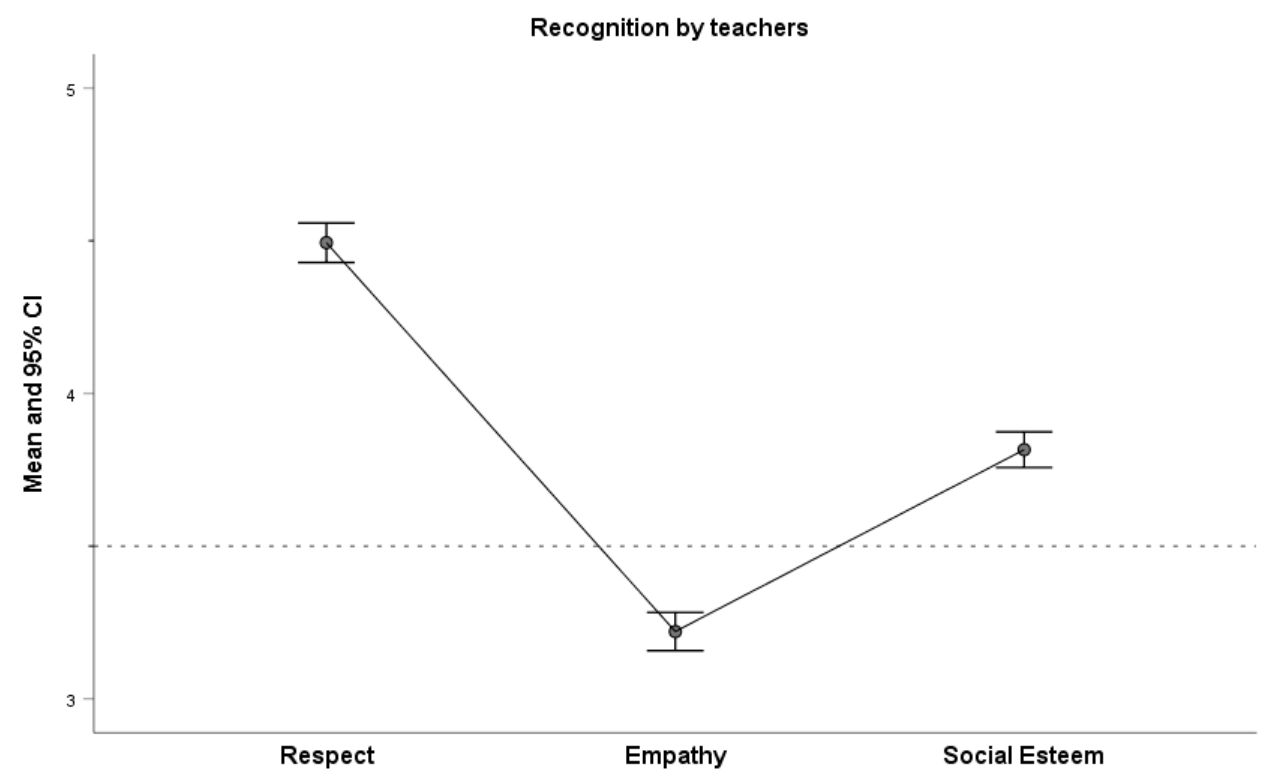

Figure 1. Mean scores of teachers' recognition sub-scales.

Table 2. Means, SDs, and Intercorrelations between the three teachers' recognition sub-scales.

\begin{tabular}{cccccc}
\hline $\begin{array}{c}\text { Recognition } \\
\text { by Teacher }\end{array}$ & N & Mean & Std. Dev. & \multicolumn{2}{c}{ Intercorrelations ${ }^{\mathbf{1}}$} \\
\hline Respect & 1248 & 4.49 & 1.15 & & Empathy \\
Empathy & 1279 & 3.22 & 1.12 & 0.513 & \\
Social esteem & 1278 & 3.82 & 1.04 & 0.623 & 0.648 \\
\hline
\end{tabular}

${ }^{1}$ All correlations were significant at the 0.001 level.

Intercorrelations between the three teachers' recognition sub-scales were high (Table 2), indicating an elevated but still distinctive relationship between the three sub-scales. 


\subsubsection{Effects of Gender, Ethnicity, and Family Education on Teacher Recognition}

For all subscales, $t$-tests comparing males with females produced significant results (Table 3). Females had higher scores than the males regarding moral respect by teachers $(\mathrm{t}[1245,98]=-3.79, p<0.001, d=0.21)$, empathy $(\mathrm{t}[1277]=-3.18, p=0.001, d=0.18])$ and social esteem $(\mathrm{t}[1276]=-2.99, p=0.003, d=0.17)$. Moreover, total scores of recognition by teachers were higher for females $(\mathrm{t}[1276]=-3.86, p<0.001, d=0.22)$.

Table 3. Comparison of recognition by teachers with respect to gender.

\begin{tabular}{cccccc}
\hline \multirow{2}{*}{$\begin{array}{c}\text { Recognition } \\
\text { by Teachers }\end{array}$} & \multicolumn{5}{c}{ Gender } \\
\cline { 2 - 6 } & Mean & S.D. & Mean & S.D. & Sig. \\
\hline nespect & 4.37 & 1.19 & 4.62 & 1.08 & $<0.001$ \\
Empathy & 3.12 & 1.09 & 3.32 & 1.14 & 0.001 \\
Social esteem & 3.73 & 1.03 & 3.91 & 1.03 & 0.003 \\
Total & 3.90 & 0.96 & 4.12 & 0.95 & $<0.001$ \\
\hline
\end{tabular}

Regarding ethnicity, $t$-tests comparing Greek with non-Greek students gave significant results for the total scores as well as for moral respect and social esteem (Table 4). Students with an immigration background had lower scores compared with natives regarding moral respect by teachers $(\mathrm{t}[548.193]=4.05, p<0.001, d=0.35])$, and social esteem $(\mathrm{t}[578.797]=4.08, p<0.001, d=0.34])$ but the difference was not significant for empathy $(\mathrm{t}[1275]=1.31, p=0.190, d=0.07)$. Native students also had higher total scores of recognition by teachers $(\mathrm{t}[542.793]=3.96, p<0.001, d=0.34)$.

Table 4. Comparison of recognition by teachers with respect to ethnicity.

\begin{tabular}{cccccc}
\hline \multicolumn{7}{c}{ Ethnicity } \\
\hline & \multicolumn{2}{c}{ Greek } & \multicolumn{2}{c}{ Non-Greek } & Sig. \\
\hline Recognition by Teachers & Mean & SD & Mean & SD & $p$ \\
\hline Respect & 4.58 & 1.09 & 4.27 & 1.24 & $<0.001$ \\
Empathy & 3.25 & 1.10 & 3.15 & 1.14 & 0.190 \\
Social esteem & 3.90 & 1.00 & 3.62 & 1.09 & $<0.001$ \\
Total & 4.08 & 0.92 & 3.82 & 1.03 & $<0.001$ \\
\hline
\end{tabular}

Recognition by teachers (total score) was significantly differentiated according to family education level $\left(F[2,1089]=3.69, p=0.025, \eta^{2}=0.007\right)$. The lower the family education the less the recognition experienced by the students, as shown by the statistically significant linear trend $(p=0.009)$. Similar results were obtained for the subscale for respect $\left(F[2,1120]=5.44, p=0.004, \eta^{2}=0.010\right)$ and social esteem $(F[2,1143]=8.20$, $\left.p<0.001, \eta^{2}=0.014\right)$. However, the result was not significant for the empathy subscale $(\mathrm{F}[2,1147]=0.86, p=0.422$; see Table 5$)$.

Table 5. Recognition by teachers with respect to family education level.

\begin{tabular}{|c|c|c|c|c|c|c|c|c|}
\hline \multirow{3}{*}{$\begin{array}{c}\text { Recognition by } \\
\text { Teachers }\end{array}$} & \multicolumn{8}{|c|}{ Family Educational Level } \\
\hline & \multicolumn{2}{|c|}{ Basic } & \multicolumn{2}{|c|}{ Secondary } & \multicolumn{2}{|c|}{ University } & \multirow[b]{2}{*}{ Sig. $p$} & \multirow[b]{2}{*}{$\eta^{2}$} \\
\hline & Mean & S.D. & Mean & S.D. & Mean & S.D. & & \\
\hline Respect & 4.20 & 1.23 & 4.46 & 1.17 & 4.59 & 1.09 & 0.004 & 0.010 \\
\hline Empathy & 3.24 & 1.12 & 3.27 & 1.10 & 3.18 & 1.13 & 0.422 & 0.002 \\
\hline Social esteem & 3.48 & 1.11 & 3.78 & 1.08 & 3.92 & 1.00 & $<0.001$ & 0.014 \\
\hline Total & 3.79 & 1.05 & 3.99 & 0.98 & 4.07 & 0.93 & 0.025 & 0.007 \\
\hline
\end{tabular}




\subsubsection{Intersectionality of Recognition by Teachers}

Total scores for recognition by teachers were analyzed using 3-way analysis of variance (ANOVA). Significant effects were found for gender and ethnicity; family education did not have a significant effect (Table 6).

Table 6. ANOVA of Recognition by teachers total score.

\begin{tabular}{ccccccc}
\hline Source & Type III Sum of Squares & df & Mean Square & F & Sig. $p$ & $\eta^{2}$ \\
\hline Gender [G] & 19.704 & 1 & 19.704 & 22.497 & $<0.001$ & 0.020 \\
Ethnicity [E] & 13.462 & 1 & 13.462 & 15.371 & $<0.001$ & 0.014 \\
Family Education [FEd] & 3.930 & 2 & 1.965 & 2.244 & 0.107 & 0.004 \\
G $\times$ E & 0.278 & 1 & 0.278 & 0.317 & 0.573 & 0.000 \\
G $\times$ FEd & 5.204 & 2 & 2.602 & 2.971 & 0.052 & 0.005 \\
E $\times$ FEd & 2.624 & 2 & 1.312 & 1.498 & 0.224 & 0.003 \\
G $\times$ E $\times$ FEd & 0.887 & 2 & 0.444 & 0.507 & 0.603 & 0.001 \\
Error & 944.134 & 1078 & 0.876 & & & \\
\hline
\end{tabular}

Three-way multivariate ANOVA (MANOVA) for the three subscales for recognition by teachers revealed a significant effect of all three socio-demographic variables, as well as a significant interaction between family education and gender, which was not shown in total scores (Table 7).

Table 7. MANOVA of Recognition by teachers subscales.

\begin{tabular}{ccccccc}
\hline Main Effects and Interactions & Roy's Largest Root & F & Hyp. df & Error df & Sig. $\boldsymbol{p}$ & $\eta \mathbf{2}$ \\
\hline Gender [G] & 0.025 & 8.936 & 3 & 1076 & $<0.001$ & 0.024 \\
Ethnicity [E] & 0.016 & 5.885 & 3 & 1076 & 0.001 & 0.016 \\
Fam. Education [FEd] & 0.019 & 6.818 & 3 & 1077 & $<0.001$ & 0.019 \\
E $\times$ FEd & 0.005 & 1.925 & 3 & 1077 & 0.124 & 0.005 \\
G $\times$ FEd & 0.009 & 3.088 & 3 & 1077 & 0.026 & 0.009 \\
G $\times$ E & 0.002 & 0.655 & 3 & 1076 & 0.580 & 0.002 \\
G $\times$ E $\times$ FEd & 0.005 & 1.705 & 3 & 1077 & 0.164 & 0.005 \\
\hline
\end{tabular}

As can be seen in Table 7, the MANOVA results revealed a significant interaction between family education and gender. Univariate tests showed that this was true for the subscale of respect only $\left(F[2,1078]=4.305, p=0.014 . \eta^{2}=0.008\right)$, while no interaction effect was found in the other two subscales. The interaction effect is illustrated in Figure 2.

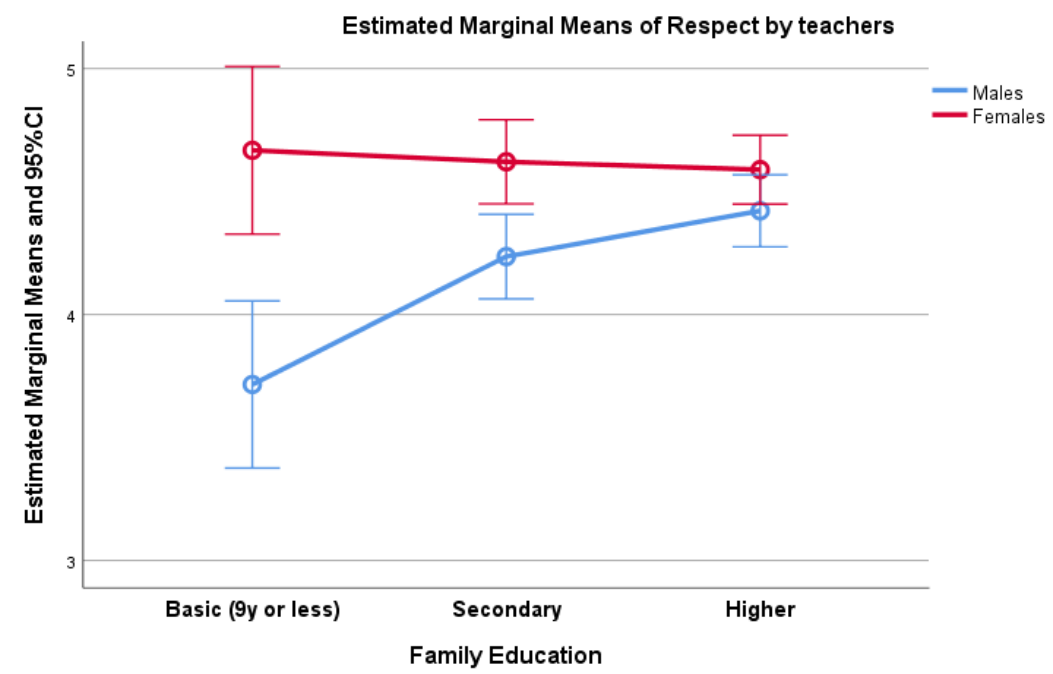

Figure 2. Interaction of Gender by Family Education regarding the Respect by teacher subscale scores. 
For females, respect from teachers was not related to family education level $(\mathrm{F}[2,1078]=4.30$, $\left.p=0.014 . \eta^{2}=0.008\right]$ ); for males, respect from teachers was significantly lower among students from families with just an elementary education $(\mathrm{F}[2,1078]=4.305, p=0.014$. $\left.\eta^{2}=0.008\right)$. Tukey's b post hoc test was used. Both male and female students experienced less social esteem from their teachers if they came from poorly educated families. However, empathy was not found to be related to family education level.

The main effects of gender were significant for all three subscales, that is, males experienced recognition by teachers to a lower degree in all domains (moral, emotional, and social). Non-Greeks also experienced less moral respect and social esteem, but they did not differ from natives in empathy.

\subsection{Recognition by Peers}

3.2.1. Subscales of Recognition by Peers

The mean scores for social esteem were just above the scale's midpoint (Figure 3 and Table 8).

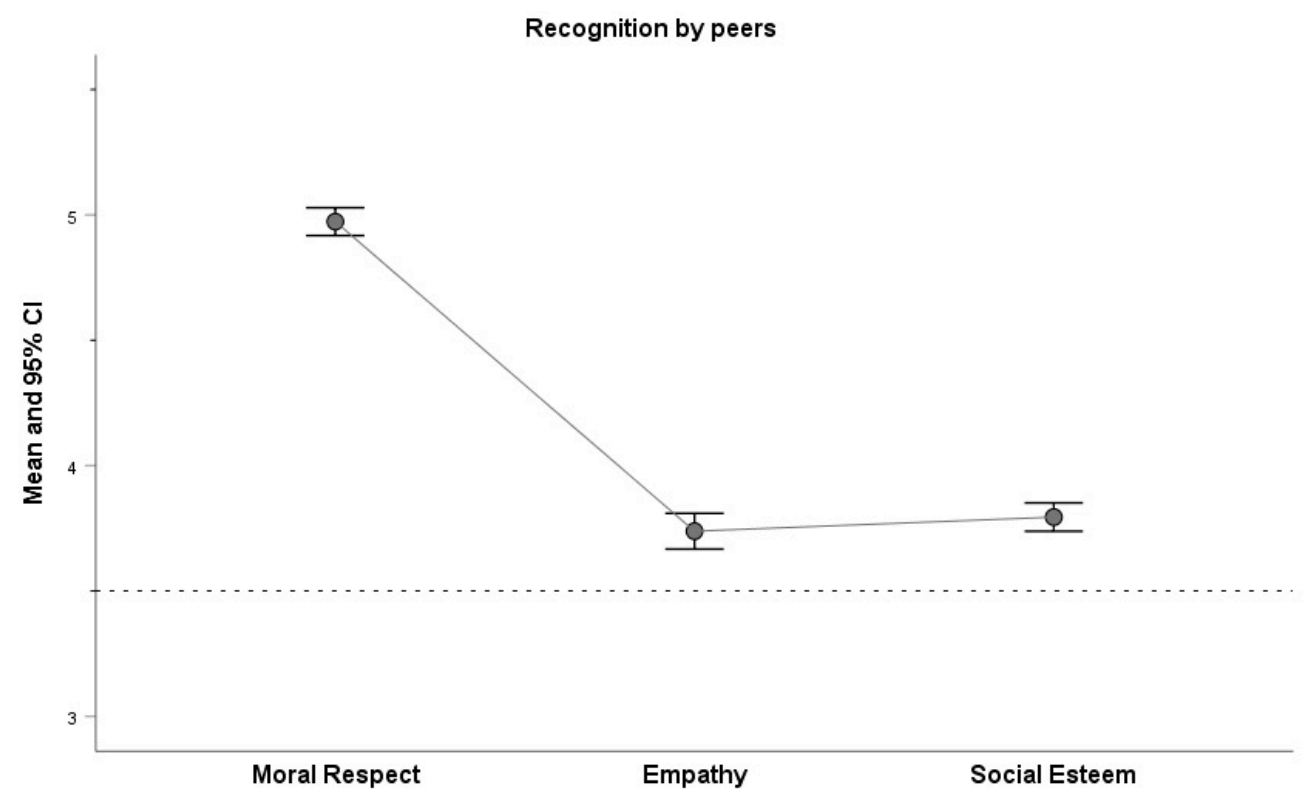

Figure 3. Mean scores of peers' recognition sub-scales.

Table 8. Means, SDs, and Intercorrelations between the three peers' recognition sub-scales.

\begin{tabular}{cccccc}
\hline \multirow{2}{*}{ Recognition by Teacher } & N & Mean & Std. Dev. & \multicolumn{2}{c}{ Intercorrelations ${ }^{\mathbf{1}}$} \\
\cline { 5 - 6 } & & & & Respect & Empathy \\
\hline Respect & 1234 & 4.97 & 0.97 & & \\
Empathy & 1265 & 3.74 & 1.24 & 0.394 & \\
Social esteem & 1262 & 3.81 & 0.99 & 0.489 & 0.614 \\
\hline
\end{tabular}

${ }^{1}$ All correlations were significant at the 0.001 level.

Intercorrelations between the three peers' recognition sub-scales are shown in Table 8. They indicate a rather high correlation of empathy with social esteem but medium or low correlations with respect.

\subsubsection{Effects of Gender, Ethnicity, and Family Education on Peers' Recognition}

For the total scale and all subscales, $t$-tests comparing males with females returned non-significant results (Table 9). 
Table 9. Comparison of recognition by peers with respect to gender.

\begin{tabular}{cccccc}
\hline \multirow{2}{*}{ Recognition by Peers } & \multicolumn{5}{c}{ Gender } \\
\cline { 2 - 6 } & \multicolumn{2}{c}{ Male } & \multicolumn{2}{c}{ Female } & Sig. \\
\cline { 2 - 6 } & Mean & S.D. & Mean & S.D. & $p$ \\
\hline Respect & 4.93 & 0.98 & 5.01 & 0.95 & 0.142 \\
Empathy & 3.73 & 1.21 & 3.75 & 1.28 & 0.770 \\
Social esteem & 3.78 & 0.99 & 3.84 & 0.99 & 0.278 \\
Total & 4.35 & 0.82 & 4.40 & 0.87 & 0.271 \\
\hline
\end{tabular}

Regarding ethnicity, $t$-tests comparing Greek with non-Greek students returned significant results for the total scores as well as for moral respect (Table 10). Students with an immigrant background had lower scores compared with natives in terms of respect by peers $(\mathrm{t}[554.41]=2.41, p=0.016, d=0.20)$ and the total score for recognition by peers $(\mathrm{t}[1172]=2.23, p=0.026, d=0.13)$, but the difference was not significant for empathy $(\mathrm{t}[1260]=1.56, p=0.119)$ or social esteem $(\mathrm{t}[1257]=1.46, p=0.143)$.

Table 10. Comparison of recognition by peers with respect to ethnicity.

\begin{tabular}{cccccc}
\hline \multicolumn{7}{c}{ Ethnicity } \\
\hline & \multicolumn{2}{c}{ Greek } & \multicolumn{2}{c}{ Non-Greek } & Sig. \\
\hline Recognition by Peers & Mean & SD & Mean & SD & $p$ \\
\hline Respect & 5.01 & 0.93 & 4.86 & 1.01 & 0.016 \\
Empathy & 3.77 & 1.25 & 3.65 & 1.23 & 0.119 \\
Social esteem & 3.84 & 0.97 & 3.74 & 1.01 & 0.143 \\
Total & 4.41 & 0.83 & 4.29 & 0.83 & 0.026 \\
\hline
\end{tabular}

Recognition by peers (total score) was significantly differentiated according to family education level $(\mathrm{F}[2,1058]=8.59, p<0.001, \eta 2=0.016)$. The lower the family education, the less the peer recognition experienced by the students, as the statistically significant linear trend showed $(p<0.001)$. Similar results were obtained for the subscales for respect $(\mathrm{F}[2,1104]=4.28, p=0.014, \eta 2=0.008)$, empathy $(\mathrm{F}[2,1136]=4.74, p=0.009, \eta 2=0.008)$, and social esteem $(\mathrm{F}[2,1135]=9.14, p<0.001, \eta 2=0.016$; Table 11).

Table 11. Recognition by peers with respect to family education level.

\begin{tabular}{|c|c|c|c|c|c|c|c|c|}
\hline \multirow{3}{*}{ Recognition by Peers } & \multicolumn{8}{|c|}{ Family Educational Level } \\
\hline & \multicolumn{2}{|c|}{ Basic } & \multicolumn{2}{|c|}{ Secondary } & \multicolumn{2}{|c|}{ University } & \multirow[b]{2}{*}{ Sig. $p$} & \multirow[b]{2}{*}{$\eta^{2}$} \\
\hline & Mean & S.D. & Mean & S.D. & Mean & S.D. & & \\
\hline Respect & 4.80 & 1.02 & 4.94 & 0.99 & 5.06 & 0.88 & 0.014 & 0.008 \\
\hline Empathy & 3.40 & 1.28 & 3.72 & 1.25 & 3.82 & 1.21 & 0.009 & 0.008 \\
\hline Social esteem & 3.44 & 1.01 & 3.80 & 1.01 & 3.90 & 0.95 & $<0.001$ & 0.016 \\
\hline Total & 4.08 & 0.88 & 4.36 & 0.86 & 4.46 & 0.79 & $<0.001$ & 0.016 \\
\hline
\end{tabular}

\subsubsection{Intersectionality of Recognition by Peers}

Total scores of recognition by peers were analyzed using a 3-way ANOVA. Significant effects were found regarding family education only. Ethnicity was no longer significant after the effect of family education was taken into account (Table 12). 
Table 12. ANOVA of Peers' Recognition total score.

\begin{tabular}{ccccccc}
\hline Source & Type III Sum of Squares & df & Mean Square & F & Sig. $p$ & $\eta^{2}$ \\
\hline Gender [G] & 2.196 & 1 & 2.196 & 3.315 & 0.069 & 0.003 \\
Ethnicity [E] & 1.074 & 1 & 1.074 & 1.622 & 0.203 & 0.002 \\
Family Education [FEd] & 6.081 & 2 & 3.040 & 4.591 & 0.010 & 0.009 \\
G $\times$ E & 0.005 & 1 & 0.005 & 0.008 & 0.931 & 0.000 \\
G $\times$ FEd & 2.055 & 2 & 1.027 & 1.551 & 0.212 \\
E $\times$ FEd & 0.122 & 2 & 0.061 & 0.092 & 0.912 \\
G $\times$ E FEd & 0.264 & 2 & 0.132 & 0.199 & 0.819 & 0.003 \\
Error & 692.663 & 1046 & 0.662 & & & \\
& R Squared $=0.022$ [Adjusted R Squared $=0.012$ ] & &
\end{tabular}

Similarly, multivariate tests of a 3-way MANOVA for the three subscales of recognition by teachers revealed a significant effect of family education only (Table 13).

Table 13. MANOVA of Peers' Recognition subscales.

\begin{tabular}{ccccccc}
\hline Main Effects and Interactions & Roy's Largest Root & F & Hyp. df & Error df & Sig. $\boldsymbol{p}$ & $\boldsymbol{\eta}^{\mathbf{2}}$ \\
\hline Gender [G] & 0.005 & 1.765 & 3 & 1044 & 0.152 & 0.005 \\
Ethnicity [E] & 0.002 & 0.680 & 3 & 1044 & 0.564 & 0.002 \\
Fam. Education [FEd] & 0.012 & 4.192 & 3 & 1045 & 0.006 & 0.012 \\
E $\times$ FEd & 0.002 & 0.617 & 3 & 1045 & 0.604 & 0.002 \\
G $\times$ FEd & 0.007 & 2.428 & 3 & 1045 & 0.064 & 0.007 \\
G $\times$ E & 0.006 & 2.039 & 3 & 1044 & 0.107 & 0.006 \\
G $\times$ E $\times$ FEd & 0.004 & 1.331 & 3 & 1045 & 0.263 & 0.004 \\
\hline
\end{tabular}

In all three subscales, there was a significant linear trend with respect to family education (Figure 4). The lower the level of family education, the less the recognition by peers.

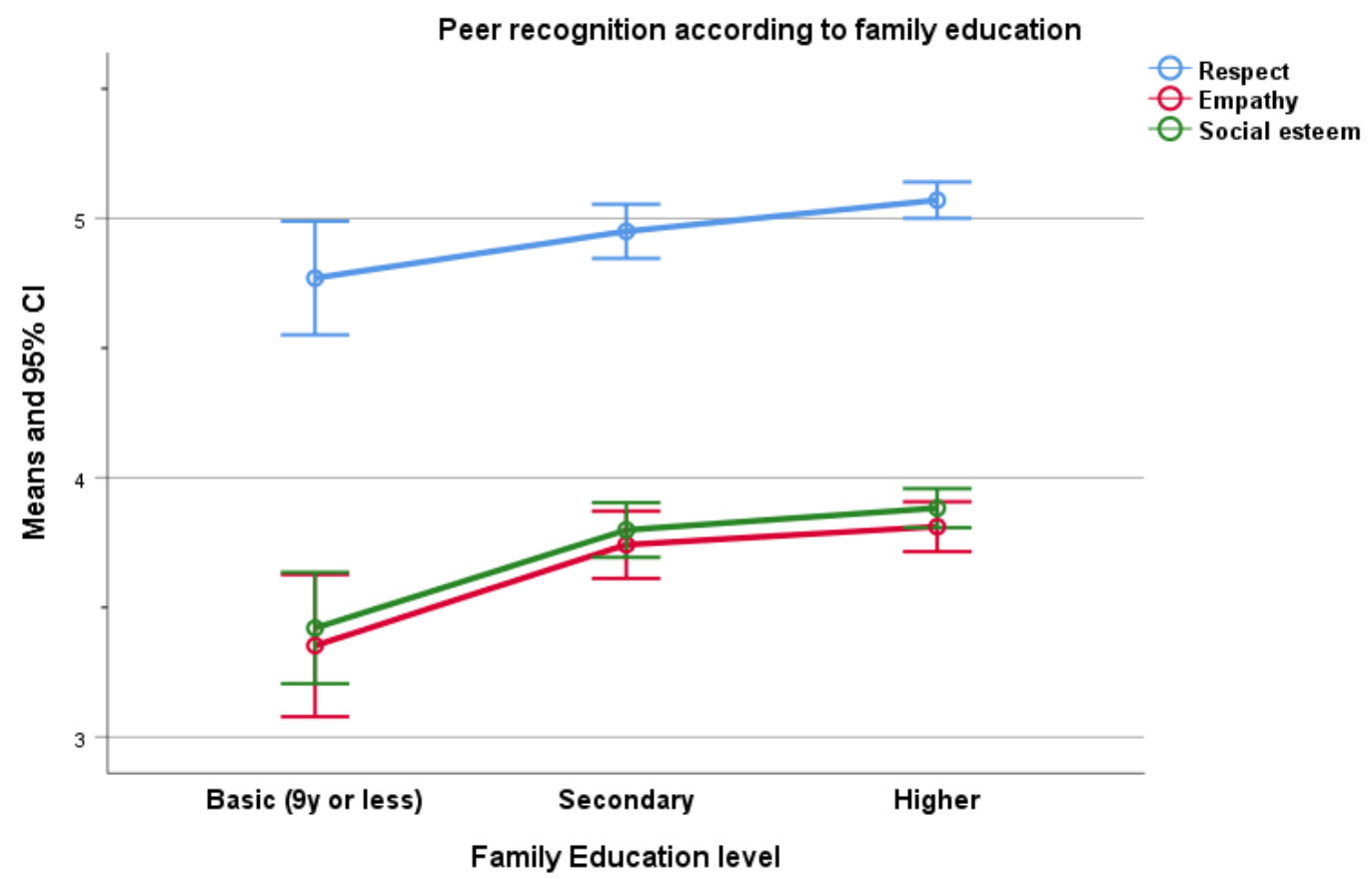

Figure 4. Estimated marginal means of peers' recognition subscales by family education level. 


\subsection{Recognition and Student Outcome Correlations}

Students' recognition by teachers was associated with those by peers $(\mathrm{r}=0.427) ; 18 \%$ of peer recognition was attributed to recognition by teachers. In particular, correlations between recognition by teachers and peers concerning respect and social esteem were of medium size, while those regarding empathy were low (Table 14).

Table 14. Correlation coefficients between Teachers' and Peers' Recognition subscales.

\begin{tabular}{cccc}
\hline \multirow{2}{*}{ Recognition by Teachers } & \multicolumn{3}{c}{ Recognition by Peers } \\
\cline { 2 - 4 } & Respect & Empathy & Social Esteem \\
\hline Respect & 0.488 & 0.092 & 0.255 \\
Empathy & 0.174 & 0.237 & 0.335 \\
Social esteem & 0.278 & 0.206 & 0.431 \\
\hline
\end{tabular}

All correlations were significant at the 0.001 level.

Table 15 shows that the recognition by teachers subscales for respect and social esteem were correlated to a medium extent with academic achievement; all the other correlations were rather low. Recognition by peers regarding respect and social esteem was correlated to an almost medium extent with self-esteem. All the other correlations were low.

Table 15. Correlation coefficients of Students' Recognition experiences with their outcomes.

\begin{tabular}{cccc}
\hline \multicolumn{2}{c}{ Recognition } & Academic Achievement & Self Esteem \\
\hline \multirow{3}{*}{ by Teachers } & Respect & 0.527 & 0.273 \\
& Empathy & 0.284 & 0.165 \\
& Social esteem & 0.474 & 0.263 \\
& Total & 0.534 & 0.289 \\
\hline \multirow{3}{*}{ by Peers } & Respect & 0.284 & 0.387 \\
& Empathy & 0.108 & 0.179 \\
& Social esteem & 0.273 & 0.337 \\
& Total & 0.209 & 0.312 \\
\hline
\end{tabular}

All correlations were significant at the 0.001 level.

\subsection{Predicting Student Outcomes}

Multiple regression of academic achievement on socio-demographic variables and students' recognition experiences showed that recognition by teachers was the most predictive factor. The contribution of peer recognition was not significant. Greek ethnicity, female gender, and an educated family were additional predictive factors for high grades. Thirty-seven percent of the variability in academic achievement can be explained by these factors. A similar analysis regarding self-esteem showed that students' recognition by peers was by far the most influential positive factor, followed by male gender and recognition by teachers (Table 16).

Table 16. Prediction of students' outcomes: regression coefficients and statistical significance.

\begin{tabular}{ccccccc}
\hline & \multicolumn{3}{c}{ Academic Achievement } & \multicolumn{2}{c}{ Self Esteem } \\
\hline Predictors & B & Std. Error & Beta & B & Std. Error & Beta \\
\hline constant & 11.668 & 0.343 & & 1.818 & 0.106 & -0.001 \\
Ethnicity [Greek] & 0.591 & 0.116 & $0.130^{* *}$ & -0.001 & 0.036 & $-0.182^{* *}$ \\
Gender [Female] & 0.532 & 0.102 & $0.133^{* *}$ & -0.193 & 0.032 & -0.022 \\
Family educ. [Higher] & 1.179 & 0.197 & $0.290^{* *}$ & -0.024 & 0.061 & -0.019 \\
Family educ. [Secondary] & 0.488 & 0.204 & $0.115^{*}$ & -0.021 & 0.018 & $0.161^{* *}$ \\
Recognition by Teachers & 1.007 & 0.059 & $0.481^{* *}$ & 0.090 & 0.021 & $0.315^{* *}$ \\
Recognition by Peers & 0.079 & 0.068 & 0.032 & 0.205 & Adj. $\mathrm{R}^{2}=0.186$ \\
\hline
\end{tabular}

* significant at the 0.05 level. ${ }^{* *}$ significant at the 0.01 level 


\section{Discussion}

Assessing, from a theoretical point of view, the deficient experiences of recognition in the form of respect and social esteem, it is important to point out that they are related and caused by two central structural elements of the educational process, which are intertwined in school everyday life: the first element concerns the opportunities and the possibilities of participation of all students at the level of teaching, as well as at the level of school life, in general, and the second element concerns the applied practices of evaluation of individual performance by the class teacher. The importance of participation in school life for building experiences of respect is confirmed by Sirlopú and Renger's research [62], which is based on Honneth's theory of recognition [22-24]. Researchers emphasize the role of participation in school life in developing experiences of recognition, in the form of respect, especially for immigrant students. Although student participation is recognized for its fundamental importance in cognitive and emotional development, it appears that in school everyday life student participation is shaped by terms that work preferentially only for those who have a high school performance and are distinguished by their communication skills. Taking this into account, Sauerwein [63] evaluates the absence of opportunities for the participation of specific groups of students, such as those with an immigrant background, as experiences of rejection by the school, which has a negative effect on their development.

From the point of view of recognitional justice, the main research issue that arises in relation to educational inequalities is the degree to which the students feel recognized by the school. This was the main focus of our research in our examination of the recognition experiences of secondary school students in Greece.

We found that there were differences in the degree of students' recognition experiences. These concerned all three forms of recognition, and they appeared on the axes of intersectionality as gender, ethnicity, and the educational level of the family. In particular, girls, native students, and students from families with a high level of education experienced the highest degree of recognition by teachers. The girls experienced greater recognition from teachers in all areas. However, differences in the experiences of recognition in terms of ethnic origin and the educational level of the family were evident in the experiences of respect and social esteem but not of empathy. Students from immigrant and low-income families experienced the lowest levels of respect and social esteem from their teachers. Vieluf and Sauerwein [37] found a low degree of recognition, but only in terms of respect among students from immigrant families.

Of particular interest is the finding regarding the interaction of gender and the educational level of the family. In particular, it was found that boys from families of a low educational level experience a significantly lower degree of recognition (mainly in the form of respect) than girls from the same group; this difference between the two genders did not occur in the group of students from families of a high educational level. Therefore, boys from low-income families (and not just migrants) experienced comparatively the largest deficits of recognition in their relationships with teachers. This has often been stated to be the case but without any empirical validation. This group seems to be in a very vulnerable situation in school [64].

Furthermore, the immigrant students, as well as the students from low-income families, experienced deficits in the forms of recognition of respect and social esteem, which, according to Helsper et al. [29,65], constitute the most basic conditions for developing socio-cognitive skills and, therefore, have the greatest impact on school performance and school adaptation. Once again, we emphasize the specific intersectional insights our study offers. Neither the boys nor the students with an immigrant background were, generally under pressure; the intersections of these socio-demographic categorizations made the difference. The importance of teachers' recognition in school performance was reflected in the findings of the present study because it was the strongest predictor of performance. Other factors such as gender (girls), ethnicity (natives), and family education (high) were less influential. This finding is in keeping with research that has highlighted the effect of the quality of relationships with teachers (in terms of acceptance and support for students) on 
school performance [66-68]. According to Prengel [69], factors that determine the quality of pedagogical relations in learning outcomes should be given more emphasis, especially in the context of large-scale international research (e.g., PISA). Recently, of course, there has been a growing interest in the study of how students experience their social relationships at school [70], although such experiences are not directly related to educational inequalities.

According to Filippatou and Ventista [71], teachers adapt their teaching practice mainly to the needs and abilities of the "average" student because they consider that their teaching in the formal classroom cannot benefit poor-learning students. While the research data on the conditions for participation by students is limited, it seems that teachers commitment to the academic performance of their students means that they do not show sufficient interest in creating quality relationships with their students [72]. It is clear that such teaching practices exclude from participation those students who have a special need for learning support, or are treated by teachers stereotypically due to their social and/or ethnic origin $[73,74]$.

Regarding Greek schools, the experience of insufficient support for secondary school students, and a consequent lack of participation in the teaching process, confirm recent OECD research results [75], in which $44 \%$ of students stated that teachers were not interested in the learning of every student; $33 \%$ stated that teachers did not give extra help to students who needed it; and 38\% stated that teachers insisted on not teaching until the students understood. Helsper et al. [65] and Wysujack [76] emphasize that differences in the degree of recognition in experiences of social esteem are related to the fact that the dominant way of evaluating students leads to the ranking of students as "strong" and "weak" based on a specific understanding of individual learning ability and a corresponding norm that assesses, in exclusively quantitative terms, the degree of response to the goal of acquiring an institutionally defined body of school knowledge and adapting to the school habitus in general. However, this works to the detriment of the real educational work of qualifying and socializing all students [46] and in particular to the detriment of disadvantaged students, such as those with a migrant background, who have the greatest need for recognition in the school environment $[1,65,77]$. Furthermore, experiences of insufficient social esteem among immigrant students may also be related to the way teachers evaluate their particular cultural and linguistic capital in the classroom. If this is seen more as an obstacle than as an ability and/or a learning resource, in any case as non-capital unrelated to the norm of cognitive and value habitus promoted by the school, then it is rather difficult to believe that teaching will enable immigrant to build unhindered experiences of social esteem.

In the present study, the existence or otherwise of differences in the degree of recognition experiences was also explored in respect of peer relationships, with the expectation of creating an overall picture of the existence or otherwise of groups of students who were negatively affected, so far as their school adjustment and progress were concerned, by the formation of social relationships within the school. It is acknowledged that these have a significant influence on students' development, especially during adolescence [78]. In particular, they have been found to affect students' self-esteem $[79,80]$ and school performance $[9,81]$. As relationships between students are influenced not only by their own rules but also the nature of the quality of their relationships with teachers [82], we were particularly interested in both whether the two were interrelated and whether socio-demographic factors played a role.

We concluded that the experiences of recognition in the group of classmates were to some extent correlated with their experiences of recognition by teachers. The greater the degree of recognition of students by teachers, mainly in the form of respect but also social esteem, the greater the degree of recognition by classmates. Kiuru et al. [5] cite several theoretical reasons why positive relationships with teachers can lead to acceptance and recognition by peers. For example, students may use positive relationships with teachers as resources to approach their classmates with positive expectations. Teachers can also act as a model for how to deal with classmates. It is vital in each case to find 
connections and continuity in the experiences of recognition in both respects. Certainly, the influence of teachers, especially with regard to the recognition potential that characterizes their pedagogical practices, is vital in shaping the quality of overall social relationships of students at school. Of course, from the point of view of recognitive justice, there is a great need to explore further how recognition experiences with teachers affect students' relationships and recognition experiences with classmates by addressing the issue through an intersectional lens.

Although experiences of recognition in relationships with classmates were not found to play a role in performance, their importance was reflected in the effect they had on students' self-esteem. This effect was even stronger than that exerted by the experiences of recognition by teachers. Moreover, gender played a positive role. By contrast, neither the ethnic origin nor the educational level of the family was found to affect self-esteem. Other studies on the effect of peer relationships on self-esteem reached similar conclusions $[80,83,84]$. Motti-Stefanidi et al [85] noted that acceptance by classmates in Greek schools functioned as a predictor of a high sense of self-esteem for both native and immigrant students.

Regarding the relationship of socio-demographic factors to the experiences of recognition by classmates, only the educational level of the family played a role. Students from families with a high level of education enjoyed a higher degree of recognition by their classmates. Asendorpf and Motti-Stefanidi [86] and Motti-Stefanidi et al. [85] have demonstrated the effect of social status on the degree of acceptance by classmates. Focusing on the different forms of recognition by classmates and the role of each of these factors, it was found that the educational level of the family was related to all forms of recognition by classmates and ethnicity was related to experiences of respect by classmates. In particular, native students experienced a higher degree of respect than their classmates. As this form of recognition expressed experiences of equal treatment and participation in the peer group, we are led to conclude that it is not only immigrant students who tend to receive unequal treatment from their peers. Immigrant students, however, are likely to be treated by their classmates as people who do not meet their regulatory expectations. According to Wiezorek [34], the degree of response to the expectations of classmates is a criterion for the degree of their recognition. Our finding is consistent with research that has shown a lower degree of sympathy with and acceptance of immigrant students and not only by their classmates $[87,88]$. It answers the question concerning the existence of a possible continuum of differences in the degree of recognition experiences between teacher-student and peer-to-peer relationships.

Based on these results, which reflect theoretical interpretations of how teacher-student relationships affect peer-to-peer relationships [5], we can conclude that the origins of feelings of unequal treatment among various less privileged students lay in their institutionalized relations with teachers. This view is reinforced by McGrath and Van Bergen [89], who concluded that a low-quality relationship between teachers and students at risk of school and social marginalization complicates students' relationships with their classmates. The low level of acceptance and unequal recognition by classmates may lead to negative consequences because adolescents have a special need for peer acceptance. This is an important factor in their school and social integration [90].

\section{Conclusions}

Relationships between teachers and students, as well as between classmates, have a significant impact on the results of school performance and school adaptation of students. From the point of view of recognitive justice, differences in these outcomes are interpreted as being unfair in the case of differences that relate to the degree to which the quality of these relationships satisfy students' need for empathy, respect, and social esteem. The expected encounters of social injustice in the classroom and by that the structural vulnerability production [91] will affect the psychological stability of the adolescents and their academic performance. These insights are considered fundamentally important for their emotional, cognitive, and social development. The results of the present study are in 
keeping with other studies, especially those concerning the unfavorable school situation that socially disadvantaged students find themselves in internationally. The recognitive justice approach allows us to go beyond the general findings; it allows us to interpret specifically the unfavorable situation immigrant students find themselves in and the educational inequalities they face as a result of the deficient functioning of their schools as a function of social injustice. This applies to other socially disadvantaged student groups as well. In particular, the insufficient recognition experiences of the respective students, both in their relations with teachers and their classmates, refer to (a) pedagogical practices within the classroom, which, from the point of view of inclusion, present significant deficits; and (b) deficits in the organization of school culture in terms of students' equal participation. A common denominator seems to be the fact that Greek schools (and perhaps not only Greek schools) have not yet adopted and implemented, to the required degree, pedagogical development policies and practices from a socially inclusive perspective.

\section{Methodological Limitations}

One limitation of the present study was its single information source, that is, the adolescents who completed our survey. Personality traits may have influenced their perceptions and reporting of recognition at school and their assessment of their interactions with peers and teachers. However, we know that students' self-reports are generally valid, so we can safely assume that problems arising from the absence of other data sources would be minor. Our model should be replicated in other countries to test its validity and the scales' reliability. We also need to understand whether the identified recognition processes at school apply similarly to different school grades and whether they are related to the respective adolescents' developmental stages. The cross-sectional character of the present study means that we cannot make claims about causalities and that our results speak only to specific factors. Longitudinal international studies might underline the connections between school recognition in adolescence and school outcomes. The modelling of the students' socio-economic level was based on just one item (their parents' level of education); a more sophisticated indicator was required. The extent to which recognition by teachers was connected to teaching practice, the respective didactic, and interactions between teachers and students were not analyzed. We therefore need a deeper understanding of these everyday communications and their connection to processes of recognition.

Author Contributions: Conceptualization, C.G., D.S., W.K., J.-O.S.; methodology, W.K., J.-O.S.; formal analysis, J.-O.S.; investigation, D.S.; writing-original draft preparation, C.G., D.S., W.K., J.-O.S.; writing-review and editing, C.G., D.S., W.K., J.-O.S., R.C.; funding acquisition, C.G., W.K. All authors have read and agreed to the published version of the manuscript.

Funding: This research was supported by The Swiss National Science Foundation (SNSF) through the NCCR - on the move, Grant number 51NF40-182897, awarded to Prof. Dr. Wassilis Kassis (University of Applied Sciences and Arts Northwestern Switzerland).

Institutional Review Board Statement: The study was approved by the ethics committee of the Department of Primary Education of the University of Thessaly, Greece.

Informed Consent Statement: Written informed consent was obtained from all students and their legal guardian involved in the study.

Data Availability Statement: The datasets for this study are still not available to the public.

Acknowledgments: We acknowledge the support given by the headmasters, teachers, and adolescents for completing this study.

Conflicts of Interest: The authors declare no conflict of interest. 


\section{References}

1. Hamre, B.K.; Pianta, R.C. Early Teacher-Child Relationships and the Trajectory of Children's School Outcomes through Eighth Grade. Child Dev. 2001, 72, 625-638. [CrossRef] [PubMed]

2. Pianta, R.C.; Stuhlman, M.W. Teacher-Child Relationships and Children's Success in the First Years of School. Sch. Psychol. Rev. 2004, 33, 444-458. [CrossRef]

3. Mc Laughlin, C.; Clarke, B. Relational matters: A review of the impact of school experience on mental health in early adolescence. Educ. Child Psychol. 2010, 27, 91-103.

4. Roorda, D.L.; Koomen, H.M.Y.; Spilt, J.L.; Oort, F.J. The Influence of Affective Teacher-Student Relationships on Students' School Engagement and Achievement: A Meta-Analytic Approach. Rev. Educ. Res. 2011, 81, 493-529. [CrossRef]

5. Kiuru, N.; Aunola, K.; Lerkkanen, M.-K.; Pakarinen, E.; Poskiparta, E.; Ahonen, T.; Poikkeus, A.-M.; Nurmi, J.-E. Positive teacher and peer relations combine to predict primary school students' academic skill development. Dev. Psychol. 2015, 51, 434-446. [CrossRef]

6. Ansari, A.; Hofkens, T.L.; Pianta, R.C. Teacher-student relationships across the first seven years of education and adolescent outcomes. J. Appl. Dev. Psychol. 2020, 71, 101200. [CrossRef]

7. Valås, H. Students with Learning Disabilities and Low-Achieving Students: Peer Acceptance, Loneliness, Self-Esteem, and Depression. Soc. Psychol. Educ. 1999, 3, 173-192. [CrossRef]

8. Guerra, R.; Rodrigues, R.B.; Aguiar, C.; Carmona, M.; Alexandre, J.; Costa-Lopes, R. School achievement and well-being of immigrant children: The role of acculturation orientations and perceived discrimination. J. Sch. Psychol. 2019, 75, 104-118. [CrossRef]

9. Wentzel, K.R.; Jablansky, S.; Scalise, N.R. Peer social acceptance and academic achievement: A meta-analytic study. J. Educ. Psychol. 2021, 113, 157-180. [CrossRef]

10. Brand, S.; Felner, R.D.; Seitsinger, A.; Burns, A.; Bolton, N. A large scale study of the assessment of the social environment of middle and secondary schools: The validity and utility of teachers' ratings of school climate, cultural pluralism, and safety problems for understanding school effects and school improvement. J. Sch. Psychol. 2008, 46, 507-535. [CrossRef]

11. Monahan, K.C.; Oesterle, S.; Hawkins, J.D. Predictors and Consequences of School Connectedness: The Case for Prevention. Prev. Res. 2010. [CrossRef]

12. Dulay, S.; Karadağ, E. The Effect of School Climate on Student Achievement. In The Factors Effecting Student Achievement; Springer: Berlin/Heidelberg, Germany, 2017; Volume 52, pp. 199-213.

13. Maxwell, S.; Reynolds, K.; Lee, E.; Subasic, E.; Bromhead, D. The Impact of School Climate and School Identification on Academic Achievement: Multilevel Modeling with Student and Teacher Data. Front. Psychol. 2017, 8, 2069. [CrossRef] [PubMed]

14. Dimitrova, R.; Chasiotis, A.; Van de Vijver, F. Adjustment Outcomes of Immigrant Children and Youth in Europe A Meta-Analysis. Eur. Psychol. 2016, 21, 150-162. [CrossRef]

15. Schachner, M.K.; van de Vijver, F.J.; Noack, P. Contextual Conditions for Acculturation and Adjustment of Adolescent ImmigrantsIntegrating Theory and Findings. Online Read. Psychol. Cult. 2017, 8, 122. [CrossRef]

16. Hopson, L.M.; Lee, E. Mitigating the effect of family poverty on academic and behavioral outcomes: The role of school climate in middle and high school. Child Youth Serv. Rev. 2011, 33, 2221-2229. [CrossRef]

17. Murray, C.; Zvoch, K. Teacher-Student Relationships among Behaviorally At-Risk African American Youth From Low-Income Backgrounds: Student Perceptions, Teacher Perceptions, and Socioemotional Adjustment Correlates. J. Emot. Behav. Disord. 2010, 19, 41-54. [CrossRef]

18. Kleen, H.; Glock, S. A further look into ethnicity: The impact of stereotypical expectations on teachers' judgments of female ethnic minority students. Soc. Psychol. Educ. 2018, 21, 759-773. [CrossRef]

19. Makarova, E.; Gilde, J.; Birman, D. Teachers as risk and resource factors in minority students' school adjustment: An integrative review of qualitative research on acculturation. Intercult. Educ. 2020, 30, 4-33. [CrossRef]

20. Nusche, D. What Works in Migrant Education? A Review of Evidence and Policy Options; OECD Publishing: Paris, France, 2009.

21. Van den Bergh, L.; Denessen, E.; Hornstra, L.; Voeten, M.; Holland, R.W. The Implicit Prejudiced Attitudes of Teachers: Relations to Teacher Expectations and the Ethnic Achievement Gap. Am. Educ. Res. J. 2010, 47, 497-527. [CrossRef]

22. Honneth, A. The Social Dynamics of Disrespect: On the Location of Critical Theory Today. Constellations 1994, 1, $255-269$.

23. Honneth, A. Anerkennung: Eine Europaeische Ideengeschichte; Suhrkamp Verlag: Frankfurt, Germany, 2018.

24. Frazer, N.; Honneth, A. Redistribution or Recognition? A Political-Philosophical Exchange; Verso Books: London, UK, 2003.

25. Stojanov, K. Bildung und Anerkennung: Soziale Voraussetzungen von Selbst-Entwicklung und Welt-Erschließung; Springer: Berlin, Germany, 2006.

26. Stojanov, K. Bildungsgerechtigkeit: Rekonstruktionen Eines Umkämften Begriffs; Springer: Berlin, Germany, 2011.

27. Stojanov, K. Bildungsgerechtigkeit als Anerkennungsgerechtigkeit. In Bildungsgerechtigkeit Jenseits von Chancengleichheit; Dietrich, F., Heinrich, M., Thieme, N., Eds.; Springer VS: Wiesbaden, Germany, 2013; pp. 57-69.

28. Stojanov, K. Education, Self-Consciousness and Social Action: Bildung as a neo-Hegelian Concept; Routledge: London, UK, 2017.

29. Helsper, W.; Lingkost, A. Schuelerpartizipation in den Antinomien von Autonomie und Zwang sowie Organisation und InteraktionExemplarische Rekonstruktionen im Horizont einer Theorie Schulischer Anerkennung; Hafeneger, B., Henkenborg, P., Scherr, A., Eds.; Wochenschau Verlag: Schwalbach/Ts, Germany, 2002; pp. 132-156.

30. Peters, R. Ethics and Education; Allen \& Unwin: London, UK, 1966. 
31. Stojanov, K. Leistung-Ein irreführender Begriff im Diskurs über Bildungsgerechtigkeit. In Leistung; Schäfer, A., Thompson, C., Eds.; Ferdinand Schöningh: Paderborn, Germany, 2015; pp. 135-150.

32. Sandring, S. Schulversagen und Anerkennung: Scheiternde Schulkarrieren im Spiegel der Anerkennungsbedürfnisse Jugendlicher; Springer VS: Wiesbaden, Germany, 2013.

33. Kammler, T. Anerkennung und Gewalt an Schulen; Springer VS: Wiesbaden, Germany, 2013.

34. Wiezorek, C. Schule, Biografie und Anerkennung: Eine fallbezogene Diskussion der Schule als Sozialisationsinstanz; Springer VS: Wiesbaden, Germany, 2005.

35. Cornelius-White, J. Learner-Centered Teacher-Student Relationships Are Effective: A Meta-Analysis. Rev. Educ. Res. 2007, 77, 113-143. [CrossRef]

36. Whitford, D.K.; Emerson, A.M. Empathy Intervention to Reduce Implicit Bias in Pre-Service Teachers. Psychol. Rep. 2018, 122, 670-688. [CrossRef] [PubMed]

37. Vieluf, S.; Sauerwein, M.N. Does a lack of teachers' recognition of students with migration background contribute to achievement gaps? Eur. Educ. Res. J. 2018. [CrossRef]

38. Lorenz, G.; Gentrup, S.; Kristen, C.; Stanat, P.; Kogan, I. Stereotype bei Lehrkräften? Eine Untersuchung systematisch verzerrter Lehrererwartungen. KZfSS Kölner Z. Soziologie Soz. 2016, 68, 89-111. [CrossRef]

39. McKown, C.; Weinstein, R.S. Teacher expectations, classroom context, and the achievement gap. J. Sch. Psychol. 2008, 46, $235-261$. [CrossRef]

40. Ready, D.D.; Chu, E.M. Sociodemographic Inequality in Early Literacy Development: The Role of Teacher Perceptual Accuracy. Early Educ. Dev. 2015, 26, 970-987. [CrossRef]

41. Tenenbaum, H.R.; Ruck, M.D. Are teachers' expectations different for racial minority than for European American students? A meta-analysis. J. Educ. Psychol. 2007, 99, 253-273. [CrossRef]

42. Pianta, R.C.; Hamre, B.K.; Allen, J.P. Teacher-Student Relationships and Engagement: Conceptualizing, Measuring, and Improving the Capacity of Classroom Interactions. In Handbook of Research on Student Engagement; Springer: Boston, MA, USA, 2012; pp. 365-386.

43. Ryan, A.M.; Patrick, H. The Classroom Social Environment and Changes in Adolescents' Motivation and Engagement During Middle School. Am. Educ. Res. J. 2001, 38, 437-460. [CrossRef]

44. Keating, A.; Janmaat, J.G. Education Through Citizenship at School: Do School Activities Have a Lasting Impact on Youth Political Engagement? Parliam. Aff. 2015, 69, 409-429. [CrossRef]

45. Wanders, F.H.K.; Dijkstra, A.B.; Maslowski, R.; Van Der Veen, I. The effect of teacher-student and student-student relationships on the societal involvement of students. Res. Pap. Educ. 2019, 35, 266-286. [CrossRef]

46. Prengel, A. Pädagogische Beziehungen zwischen Anerkennung, Verletzung und Ambivalenz; Verlag Barbara Budrich: Leverkusen, Germany, 2013.

47. Gottburgsen, A.; Gros, C. Welchen Beitrag leistet Intersektionalität“ zur Klärung von Kompetenzunterschieden bei Jugendlichen? In Soziologische Bildungsforschung; Becker, R., Solga, S., Eds.; Springer VS: Wiesbaden, Germany, 2012; pp. 86-110.

48. McMaster, N.C.; Cook, R. The contribution of intersectionality to quantitative research into educational inequalities. Rev. Educ. 2018, 7, 271-292. [CrossRef]

49. Klinger, C.; Knapp, G.-A.; Sauer, B. Achsen der Ungleichheit. Zum Verhältnis von Klasse, Geschlecht und Ethnizität; Campus Verlag: Frankfurt, Germany, 2007.

50. Kassis, W.; Kronig, W.; Stalder, U.; Weber, M. Bildungsprozesse und Interesektionalitaetsstrukturen. In Kulturen der Bildung. Opladen E Farmington Hills; Melzer, W., Tippelt, R., Eds.; Verlag Barbara Budrich: Leverkusen, Germany, 2009; pp. $339-348$.

51. Crenshaw, K. Demarginalising the intersection of race and sex: A black feminist critique of antidiscrimination doctrine, feminist theory and antiracist politics. Univ. Chic. Crit. Leg. Forum 1989, 139, 139-167.

52. Jang, S.T. The Implications of Intersectionality on Southeast Asian Female Students' Educational Outcomes in the United States: A Critical Quantitative Intersectionality Analysis. Am. Educ. Res. J. 2018, 55, 1268-1306. [CrossRef]

53. Bešić, E. Intersectionality: A pathway towards inclusive education? Prospects 2020, 49, 111-122. [CrossRef]

54. McCall, L. The complexity of intersectionality. Signs J. Women Cult. Soc. 2005, 30, 1771-1800. [CrossRef]

55. Bilecen, B. Personal network analysis from an intersectional perspective: How to overcome ethnicity bias in migration research. Glob. Netw. 2021, 21, 470-486. [CrossRef]

56. Gregoriou, Z. Traversing New Theoretical Frames for Intercultural Education: Gender, Intersectionality, Performativity. Int. Educ. Stud. 2013, 6, 179. [CrossRef]

57. Westbrook, L.; Saperstein, A. New Categories Are Not Enough. Gend. Soc. 2015, 29, 534-560. [CrossRef]

58. Bastia, T. Intersectionality, migration and development. Prog. Dev. Stud. 2014, 14, 237-248. [CrossRef]

59. Nelson, J.D.; Stahl, G.; Wallace, D. Race, class and gender in boy's education: Repositioning intersectionality theory. Cult. Soc. Masc. 2015, 7, 171-187. [CrossRef]

60. Tefera, A.A.; Powers, J.M.; Fischman, G. Intersectionality in Education: A Conceptual Aspiration and Research Imperative. Rev. Res. Educ. 2018, 42. [CrossRef]

61. Honneth, A. Verdinglichung: Eine Anerkennungstheoretische Studie; Suhrkamp Verlag: Frankfurt, Germany, 2015.

62. Sirlopú, D.; Renger, D. Social recognition matters: Consequences for school participation and life satisfaction among immigrant students. J. Community Appl. Soc. Psychol. 2020, 30, 561-575. [CrossRef] 
63. Sauerwein, M. Partizipation in der Ganztagsschule-Vertiefende Analysen. Z. Erzieh. 2019, 22, 435-459. [CrossRef]

64. Becker, R.; Walter, M. Bildungsungleichheiten nach Geschlecht und Herkunft im Wandel. In Geschlechtsspezifische Bildungsungleichheiten; Hadjar, A., Ed.; VS Verlag für Sozialwissenschaften: Wiesbaden, Germany, 2011; pp. 55-75.

65. Helsper, W.; Sandring, S.; Wiezorek, C. Anerkennung in pädagogischen Beziehungen Ein Problemaufriss. In Integrationspotenziale Einer Modernen Gesellschaft; VS Verlag für Sozialwissenschaften: Wiesbaden, Germany, 2005; pp. 179-206.

66. Lee, J.-S. The effects of the teacher-student relationship and academic press on student engagement and academic performance. Int. J. Educ. Res. 2012, 53, 330-340. [CrossRef]

67. Hattie, J.A.C. Lernen Sichtbar Machen; Beywl, W., Zierer, K., Eds.; Schneider Verlag Hohengehren: Baltmannsweiler, Germany, 2015.

68. Pianta, R.C. Children cannot be successful in the classroom unless they are successful in relationships-Analysen und Interventionen zur Verbesserung von Lehrer-Schueler-Beziehungen. In Kinderrechte in Paedagogischen Beziehungen; Prengel, A., Winklhofer, U., Eds.; Verlag Barbara Budrich: Leverkusen, Germany, 2014; pp. 127-142.

69. Prengel, A. Paedagogische Beziehungen im Lichte der Kinderrechte. In Paedagogische Beziehungen Grundlagen-PraxisformenWirkungen; Herrmann, U., Ed.; Beltz Juventa: Weinheim, Germany, 2019; pp. 73-82.

70. Schleicher, A.; Belfali, Y. The Resilience of Students with an Immigrant Background; OECD Publishing: Paris, France, 2018.

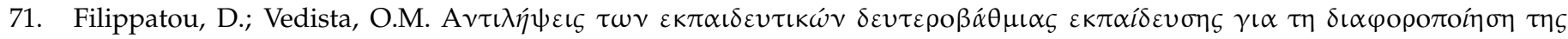

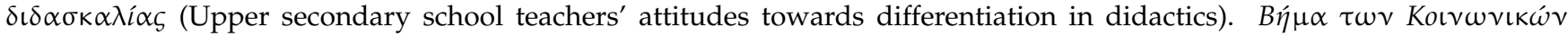

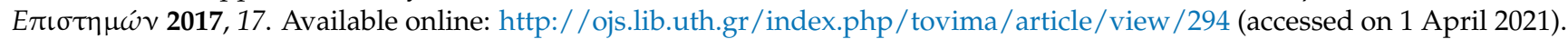

72. Krane, V.; Karlsson, B.; Ness, O.; Binder, P.-E. They need to be recognized as a person in everyday life: Teachers' and helpers' experiences of teacher-student relationships in upper secondary school. Int. J. Qual. Stud. Health Well-Being 2016, $11,31634$. [CrossRef] [PubMed]

73. Glock, S.; Klapproth, F. Bad boys, good girls? Implicit and explicit attitudes toward ethnic minority students among elementary and secondary school teachers. Stud. Educ. Eval. 2017, 53, 77-86. [CrossRef]

74. Glock, S.; Krolak-Schwerdt, S.; Klapproth, F.; Böhmer, M. Beyond judgment bias: How students' ethnicity and academic profile consistency influence teachers' tracking judgments. Soc. Psychol. Educ. 2013, 16, 555-573. [CrossRef]

75. OECD. Teachers' Support and Teaching Practices [Volume III] in Results PISA 2018: What School Life Means for Students' Lives; OECD: Paris, France, 2019.

76. Wysujack, V. Interaktive Handlungsweisen von Lehrpersonen unter Anerkennungstheoretischer Perspektive; Springer Fachmedien Wiesbaden GmbH: Wiesbaden, Germany, 2021.

77. Liew, J.; McTigue, E.M. Educating the whole child: The role of social and emotional development in achievement and school success. In Handbook of Curriculum Development; Kattington, L.E., Ed.; Nova Sciences Publishers, Inc.: Hauppauge, NY, USA, 2010; pp. 465-478. Available online: https: / / www.researchgate.net/publication/267952676 (accessed on 23 March 2021).

78. Brown, B.B.; Larson, J. Peer Relationships in Adolescence. In Handbook of Adolescent Psychology: Contextual Influences on Adolescent Development; John Wiley \& Sons, Inc.: Hoboken, NJ, USA, 2009.

79. Birkeland, M.S.; Breivik, K.; Wold, B. Peer Acceptance Protects Global Self-esteem from Negative Effects of Low Closeness to Parents During Adolescence and Early Adulthood. J. Youth Adolesc. 2013, 43, 70-80. [CrossRef]

80. Tetzner, J.; Becker, M.; Maaz, K. Development in multiple areas of life in adolescence: Interrelations between academic achievement, perceived peer acceptance, and self-esteem. Int. J. Behav. Dev. 2016, 41, 704-713. [CrossRef]

81. Juvonen, J.; Knifsend, C.A. School based peer relationshipsand achievement motivation. In Handbook of Motivation at School; Wentzel, K.R., Miele, D.B., Eds.; Routledg: New York, NY, USA, 2016.

82. Farmer, T.W.; Lines, M.M.; Hamm, J.V. Revealing the invisible hand: The role of teachers in children's peer experiences. J. Appl. Dev. Psychol. 2011, 32, 247-256. [CrossRef]

83. Flook, L.; Repetti, R.L.; Ullman, J.B. Classroom Social Experiences as Predictors of Academic Performance. Dev. Psychol. 2005, 41, 319-327. [CrossRef]

84. Reitz, A.K.; Motti-Stefanidi, F.; Asendorpf, J.B. Me, us, and them: Testing sociometer theory in a socially diverse real-life context. J. Pers. Soc. Psychol. 2016, 110, 908-920. [CrossRef]

85. Motti-Stefanidi, F.; Pavlopoulos, V.; Mastrotheodoros, S.; Asendorpf, J.B. Longitudinal interplay between peer likeability and youth's adaptation and psychological well-being: A study of immigrant and nonimmigrant adolescents in the school context. Int. J. Behav. Dev. 2020, 44, 393-403. [CrossRef]

86. Asendorpf, J.B.; Motti-Stefanidi, F. A longitudinal study of immigrants' peer acceptance and rejection: Immigrant status, immigrant composition of the classroom, and acculturation. Cult. Divers. Ethn. Minor. Psychol. 2017, 23, 486-498. [CrossRef]

87. Bianchi, D.; Cavicchiolo, E.; Lucidi, F.; Manganelli, S.; Girelli, L.; Chirico, A.; Alivernini, F. School Dropout Intention and Self-esteem in Immigrant and Native Students Living in Poverty: The Protective Role of Peer Acceptance at School. Sch. Ment. Health 2021, 13, 266-278. [CrossRef]

88. Motti-Stefanidi, F.; Pavlopoulos, V.; Obradović, J.; Dalla, M.; Takis, N.; Papathanassiou, A.; Masten, A.S. Immigration as a risk factor for adolescent adaptation in Greek urban schools. Eur. J. Dev. Psychol. 2008, 5, 235-261. [CrossRef]

89. McGrath, K.F.; Van Bergen, P. Who, when, why and to what end? Students at risk of negative student-teacher relationships and their outcomes. Educ. Res. Rev. 2015, 14, 1-17. [CrossRef] 
90. Suárez-Orozco, C.; Motti-Stefanidi, F.; Marks, A.; Katsiaficas, D. An integrative risk and resilience model for understanding the adaptation of immigrant-origin children and youth. Am. Psychol. 2018, 73, 781-796. [CrossRef]

91. Eriksen, C.; Simon, G. The Affluence-Vulnerability Interface: Intersecting scales of risk, privilege and disaster. Environ. Plan A Econ. Space 2016, 49, 293-313. [CrossRef] 